\title{
Peraturan Menteri Pertanian Republik Indonesia Nomor 36/Permentan/LB.070/8/2016 tentang Pengkajian Keamanan Pakan Produk Rekayasa Genetik
}

\author{
(Regulation of the Minister of Agriculture of the Republic of Indonesia No. \\ 36/Permentan/LB.070/8/2016 on Feed Safety Assessment of Genetic \\ Engineering Products)
}

\author{
Muharsini $\mathrm{S}^{1}$, Tiesnamurti $\mathrm{B}^{2}$ \\ ${ }^{1}$ Anggota Tim Teknis Keamanan Hayati Produk Rekayasa Genetik Bidang Pakan \\ ${ }^{2}$ Koordinator Tim Teknis Keamanan Hayati Produk Rekayasa Genetik Bidang Pakan \\ Pusat Penelitian dan Pengembangan Peternakan, Jl. Raya Pajajaran Kav. E-59, Bogor 16128 \\ niniek122@yahoo.com; criansci@indo.net.id
}

\begin{abstract}
In Indonesia there has been a reduction in agricultural land and grazing due to land conversion and climate change impact. On the other hand the demand for feed, especially grains and oilcake continues to increase. The use of genetic engineering technology is needed to meet the feed requirements, but there are pros and cons to the utilization of these genetic engineering products. Utilization of plant genetically modified products has grown rapidly in the world in the last 20 years. Indonesia has taken advantage of genetically engineered product technology, but a careful principle is required in adopting and utilizing this technology to avoid negative impacts. Legal umbrella is required in the utilization of this technology to protect the community. The Regulation of the Minister of Agriculture on the Assessment of Genetically Engineered Product of Feed Safety has been published in August 2016. The Regulation of the Minister of Agriculture consists of six chapters, 13 articles and four appendices. Furthermore, the Regulation of the Minister of Agriculture is detailed in the Decree of the Head of the Indonesia Agency for Agricultural Research and Development on Technical Guidelines of Procedures and Mechanism of Assessment of Genetically Engineered Product on Feed Safety in November 2016. In this paper Regulation of the Minister of Agriculture and Director General of IAARD Decree will be described in the framework of socialization, so that people well inform.
\end{abstract}

Key Words: Regulation of the Minister of Agriculture, Genetically Enginereed Product, Feed Safety, Procedure and Mechanism of Assessment

\begin{abstract}
ABSTRAK
Di Indonesia telah terjadi pengurangan lahan pertanian dan penggembalaan di antaranya akibat dari alih fungsi lahan dan dampak perubahan iklim. Di lain pihak, kebutuhan pakan terutama biji-bijian dan bungkil terus meningkat. Penggunaan teknologi rekayasa genetik diperlukan untuk memenuhi kebutuhan pakan, namun terdapat pro dan kontra terhadap pemanfaatan produk rekayasa genetik ini. Pemanfaatan tanaman produk rekayasa genetik telah berkembang pesat di dunia dalam 20 tahun terakhir. Indonesia telah memanfaatkan teknologi produk rekayasa genetik, namun diperlukan prinsip kehatian-hatian dalam mengadopsi dan memanfaatkan teknologi ini untuk menghindari dampak negatif. Diperlukan payung hukum dalam pemanfaatan teknologi ini untuk melindungi masyarakat. Peraturan Menteri Pertanian tentang Pengkajian Keamanan Pakan Produk Rekayasa Genetik telah diterbitkan pada bulan Agustus 2016. Peraturan Menteri Pertanian ini terdiri dari enam bab, 13 pasal dan empat lampiran. Selanjutnya Peraturan Menteri Pertanian tersebut dirinci dalam Surat Keputusan Kepala Badan Penelitian dan Pengembangan Pertanian tentang Pedoman Teknis Tata Cara dan Mekanisme Pengkajian Keamanan Pakan Produk Rekayasa Genetik pada bulan November 2016. Dalam makalah ini Peraturan Menteri Pertanian dan Surat
\end{abstract}


Keputusan Kepala Balitbangtan akan diuraikan dalam rangka sosialisasi agar masyarakat memahaminya.

Kata Kunci: Peraturan Menteri Pertanian, Produk Rekayasa Genetik, Keamanan Pakan, Tata Cara dan Mekanisme Pengkajian

\section{PENDAHULUAN}

Pembangunan pertanian di Indonesia mengalami permasalahan yang diakibatkan diantaranya adanya konversi lahan dan dampak perubahan iklim global. Luas lahan pertanian terus menyusut akibat konversi lahan pertanian produktif ke non-produktif yang terjadi secara masif digunakan untuk pemukiman (real estate), pabrik atau infrastruktur lain untuk aktivitas industri. Laju konversi lahan sawah mencapai 100 ribu hektar per tahun dimana $80 \%$ terjadi di wilayah sentra produksi pangan nasional di Pulau Jawa (Kementan 2015). Hal tersebut juga berimplikasi terhadap usaha peternakan, umumnya menggunakan lahan penggembalaan namun tergusur untuk kepentingan pemukiman atau usaha lain. Berkurangnya lahan produktif ini diperparah dengan penurunan kualitas lahan. Dengan ketersediaan lahan yang semakin sempit dan kebutuhan pangan dan pakan ternak yang meningkat maka dibutuhkan teknologi inovatif tanaman yang mampu berproduksi tinggi dan beradaptasi terhadap menurunnya kualitas lahan.

Dampak perubahan iklim global ditandai dengan perubahan pola dan intensitas curah hujan, makin sering terjadi fenomena iklim ekstrem el-nino dan la-nina, yang menimbulkan kekeringan dan banjir, kenaikan suhu udara dan permukaan air laut, sehingga mempengaruhi ketersediaan pangan maupun pakan ternak. Sejak tahun 1989 suhu bumi naik satu derajat atau peningkatan suhu $0,002^{\circ} \mathrm{C}$ per tahun. Kondisi tersebut mengganggu pertumbuhan tanaman untuk kebutuhan pangan maupun pakan sehingga dibutuhkan tanaman adaptif menghadapi perubahan iklim seperti tanaman tahan hama dan penyakit, toleran kekeringan, toleran genangan dan salinitas tinggi (James 2015). Perakitan tanaman adaptif menghadapi perubahan iklim telah dilakukan di negara-negara maju dalam rangka strategi memenuhi kebutuhan pangan dengan memanfaatkan teknologi rekayasa genetik pada tanaman pangan utama yaitu jagung dan kedelai.

Jagung, bungkil kedelai, dedak, polard dan bungkil inti sawit merupakan bahan pakan utama ternak selain hijauan. Kebutuhan jagung pada tahun 2016 adalah 13,8 juta ton yaitu 8,6 juta ton untuk pakan (termasuk untuk pakan ikan) dan 5,2 juta ton untuk pangan (Kemenperin 2016). Kekurangan pasokan jagung sebesar 3 juta ton pada tahun 2016 dipenuhi dari impor yaitu dari India, Brazil, Thailand dan Amerika Serikat. Menurut data BPS, produksi jagung pada tahun 2016 adalah 23,58 juta ton atau naik sekitar 20,23\% dibandingkan dengan data tahun 2015 yaitu 19,61 juta ton (Gideon 2017), sementara realisasi impor jagung tahun 2016 adalah 0,6 juta ton (Idris 2017). Pemerintah mentargetkan produksi jagung dalam negeri 25,2 juta ton pada tahun 2017, sementara kebutuhan jagung termasuk untuk industri adalah 20 juta ton (Idris 2017). Dengan demikian, diharapkan target stop impor jagung dapat tercapai karena terdapat surplus produksi jagung dalam negeri dan swasembada jagung dapat terwujud pada akhir tahun 2017 (Gideon 2017). Kebutuhan bungkil kedelai untuk pakan ternak 100\% impor dari negara-negara Brazil, Argentina, USA dan India. Kebutuhan impor bungkil kedelai adalah 2,57 juta ton tahun 2015 dan diperkirakan naik sekitar 8\% pada tahun 2016 (Sudirman 2015).

Indonesia mengimpor jagung dan kedelai untuk pangan dan pakan serta bungkil kedelai untuk pakan dari negara-negara pengekspor komoditas tersebut. Pada saat ini beberapa tanaman produk rekayasa genetik (PRG) yang digunakan untuk pakan telah mendapatkan sertifikat aman pakan di antaranya adalah jagung tahan penggerek Mon 
89034 dan jagung toleran herbisida NK603. Beberapa tanaman PRG juga sedang dalam proses pengkajian keamanan pakan yaitu jagung PRG tahan penggerek batang Bt11 dan jagung toleran herbisida GA21 dan tebu toleran kekeringan NXI-4T (Tiesnamurti et al. 2016). Sejumlah 18 tanaman PRG dari tiga komoditas jagung, kedelai dan tebu sudah dinyatakan aman pangan oleh Badan Pengawas Obat dan Makanan. Dalam rangka mendukung prinsip kehati-hatian (precautionary approach) dan menghindari potensi dampak negatif, maka diterbitkan payung hukum berupa Peraturan Menteri Pertanian Nomor 36/Permentan/LB.070/8/2016 tentang Pengkajian Keamanan Pakan Produk Rekayasa Genetik. Permentan tersebut selanjutnya dirinci dalam Surat Keputusan Kepala Badan Penelitian dan Pengembangan Pertanian Nomor 466.2/Kpts/OT.210/H/11/2016 tentang Pedoman Teknis Tata Cara dan Mekanisme Pengkajian Keamanan Pakan Produk Rekayasa Genetik. Dalam makalah ini, Permentan dan Surat Keputusan Kepala Balitbangtan tersebut diuraikan dalam rangka sosialisasi agar dapat dipahami oleh berbagai pihak.

\section{DASAR HUKUM PERMENTAN NOMOR 36 TAHUN 2016}

Pemerintah Republik Indonesia telah mempunyai Undang-Undang Nomor 21 Tahun 2004 tentang Pengesahan Cartagena Protocol on Biosafety to the Convention on Biological Diversity (Protokol Cartagena tentang Keamanan Hayati atas Konvensi tentang Keanekaragaman Hayati). Dalam Pasal 11 telah disebutkan prosedur pemanfaatan produk rekayasa genetik (PRG) sebagai pangan atau pakan atau untuk pengolahan. Sebagai implementasi dari UU tersebut maka diterbitkan Peraturan Pemerintah Nomor 21 tahun 2005 tentang Keamanan Hayati Produk Rekayasa Genetik. Keamanan hayati PRG adalah keamanan lingkungan, keamanan pangan dan/atau keamanan pakan PRG. Keamanan pakan PRG adalah kondisi dan upaya yang diperlukan untuk mencegah kemungkinan timbulnya dampak yang merugikan dan membahayakan kesehatan hewan dan ikan akibat proses produksi, penyiapan, penyimpanan, peredaran dan pemanfaatan pakan PRG. Beberapa pertimbangan melakukan pengkajian keamanan pakan PRG adalah: (1) Bahwa PRG selain memiliki keunggulan juga mempunyai risiko terhadap kesehatan manusia, hewan dan lingkungan; dan (2) Untuk meminimalkan risiko terhadap kesehatan manusia, hewan dan lingkungan.

\section{ISI PERMENTAN}

Permentan Nomor 36 tahun 2016 berisi enam bab, 13 pasal dan empat lampiran. Bab I berisi ketentuan umum, tujuan diterbitkannya Permentan dan ruang lingkup pengkajian. Permentan disusun sebagai dasar hukum dalam pelaksaan pengkajian terhadap keamanan pakan PRG untuk menjamin keamanan pakan PRG. Bab I berisi tiga pasal, di mana pada Pasal 1 adalah ketentuan umum yang berisi istilah-istilah yang digunakan pada Permentan ini. Pakan rekayasa genetik atau organisme hasil modifikasi adalah organisme hidup, bagian-bagiannya dan/atau hasil olahannya yang mempunyai susunan genetik baru dari hasil penerapan bioteknologi modern. Keamanan pakan PRG adalah kondisi dan upaya yang diperlukan untuk mencegah kemungkinan timbulnya dampak yang merugikan dan membahayakan kesehatan hewan dan ikan akibat proses produksi, penyaiapan, penyimpanan, peredaran dan pemanfaatan pakan PRG. Pengkajian merupakan keseluruhan proses pemeriksaan dokumen dan pengujian PRG serta faktor sosial-ekonomi terkait.

Proses pengkajian dan evaluasi keamanan hayati serta kelayakan pemanfaatan pakan PRG dilakukan oleh Tim Teknis Keamanan Pakan PRG yang dibentuk dan bertugas membantu Komisi Keamanan Hayati PRG yaitu komisi yang mempunyai tugas memberi 
rekomendasi kepada menteri, menteri berwenang dan Kepala LPNK dalam menyusun dan menetapkan serta menerbitkan sertifikat keamanan hayati PRG. Jenis pakan PRG yang masuk dalam ruang lingkup pengkajian adalah: (1) Tanaman PRG, bahan asal tanaman PRG dan hasil olahannya; (2) Jasad renik PRG, bahan asal jasad renik PRG dan olahannya; (3) Ikan PRG, bahan asal ikan PRG dan hasil olahannya; dan (4) Hewan PRG, bahan asal hewan PRG dan hasil olahannya.

\section{Syarat pengkajian keamanan pakan PRG}

Beberapa syarat pengkajian pakan PRG yaitu:

1. Pakan PRG yang akan diedarkan wajib dilengkapi sertifikat Keamanan Pakan PRG yang diberikan oleh Menteri Pertanian setelah mendapat rekomendasi keamanan pakan PRG;

2. Rekomendasi keamanan pakan PRG diberikan oleh KKH PRG setelah dilakukan pengkajian terhadap keamanan pakan PRG;

3. Untuk memperoleh sertifikat keamanan pakan PRG, pemohon mengajukan permohonan kepada Menteri Pertanian melalui Kepala Balitbangtan sesuai dengan format yang telah dilampirkan pada permentan;

4. Permohonan dapat diajukan oleh badan usaha, perguruan tinggi, instansi pemerintah dengan dilengkapi persyaratan yang ditentukan pada permentan;

5. Selain memenuhi persyaratan di atas, maka harus melengkapi informasi genetik pakan PRG dan informasi keamanan pakan PRG;

6. Informasi genetik pakan PRG yang dimaksud adalah: (a) Deskripsi umum pakan PRG; (b) Deskripsi inang dan penggunaannya sebagai pakan PRG; (c) Deskripsi organisme donor; (d) Deskripsi modifikasi genetik; dan (e) Karakterisasi modifikasi genetik;

7. Informasi keamanan pakan PRG meliputi: (a) Kesepadanan substansial; (b) Perubahan nutrisi; (c) Toksisitas; dan (d) Pertimbangan lain-lain;

8. Dalam hal pakan PRG berasal dari luar negeri selain harus dilengkapi dengan informasi genetik pakan PRG dan informasi keamanan pakan PRG, maka harus juga dilengkapi dengan surat keterangan yang menyatakan pakan tersebut telah diijinkan untuk diperdagangkan secara secara bebas (certificate of free trade) di negara asal dan ada dokumen pengkajian dan pengelolaan risiko dari institusi yang berwenang dimana pengkajian risiko pernah dilakukan.

\section{Tata cara dan mekanisme pengkajian keamanan pakan PRG}

Pedoman tata cara dan mekanisme pengkajian keamanan pakan produk rekayasa genetik mengikuti Keputusan Kepala Badan Penelitian dan Pengembangan Pertanian Nomor 446.2/Kpts/OT.210/H/11/2016 (Balitbangtan 2016). Setiap badan usaha, perguruan tinggi, instansi pemerintah yang akan mengedarkan pakan PRG mengajukan permohonan pengkajian keamanan pakan PRG secara tertulis kepada Menteri Pertanian c.q. Kepala Badan Penelitian dan Pengembangan Pertanian. Pemohon mengisi formulir dan menjawab daftar pertanyaan ruang lingkup surat keputusan Kepala Balitbangtan meliputi tata cara permohonan pengkajian keamanan pakan PRG dan mekanisme pengkajian keamanan pakan PRG, serta daftar pertanyaan yang perlu diisi oleh pemohon. Formulir dicantumkan di Lampiran I Permentan Nomor 36 Tahun 2016, sedangkan daftar pertanyaan terdapat pada Bab III Surat Keputusan Kepala Balitbangtan Nomor 446.2/Kpts/OT.210/H/11/2016 (Lampiran 1). 


\section{Alur tata cara permohonan}

Alur tata cara permohonan serifikat keamanan pakan disampaikan pada Gambar 1 . Pemohon mengirim surat dilengkapi dengan dokumen kepada Menteri Pertanian (c.q. Kepala Balitbangtan u.p. Bagian Kerja Sama Humas, Organisasi dan Hukum). Selanjutnya Balitbangtan bersurat ke Komisi Keamanan Hayati (KKH) apabila persyaratan dokumen telah lengkap. KKH menugaskan Tim Teknis Keamanan Hayati Bidang Pakan PRG (TTKH Pakan PRG) untuk mengkaji dokumen selama 56 hari kalender. Apabila diperlukan, maka KKH juga menugaskan Tim Pengkaji Bidang Hukum, Sosial Budaya dan Ekonomi (Tim PHSBE) selama 56 hari. Apabila pengkajian telah selesai, maka KKH akan memaparkan hasil pengkajian tersebut ke Balai Kliring Keamanan Hayati (BKKH) selama 60 hari untuk mendapatkan umpan balik dari publik/masyarakat. Setelah dipaparkan di BKKH, kemudian KKH menyampaikan rekomendasi aman pakan kepada Menteri Pertanian untuk diterbitkan sertifikat aman pakan kepada pemohon. Total jumlah hari yang diperlukan bagi pemohon sampai mendapatkan sertifikat aman pakan adalah 206 hari. Apabila dianggap ada data yang kurang memadai sehingga TTKH perlu tambahan data atau penjelasan yang tentu saja akan menambah hari pengkajian dokumen. Pada kondisi yang demikian, maka hitungan hari dihentikan, hingga pemohon melengkapi data atau memberikan penjelasannya.

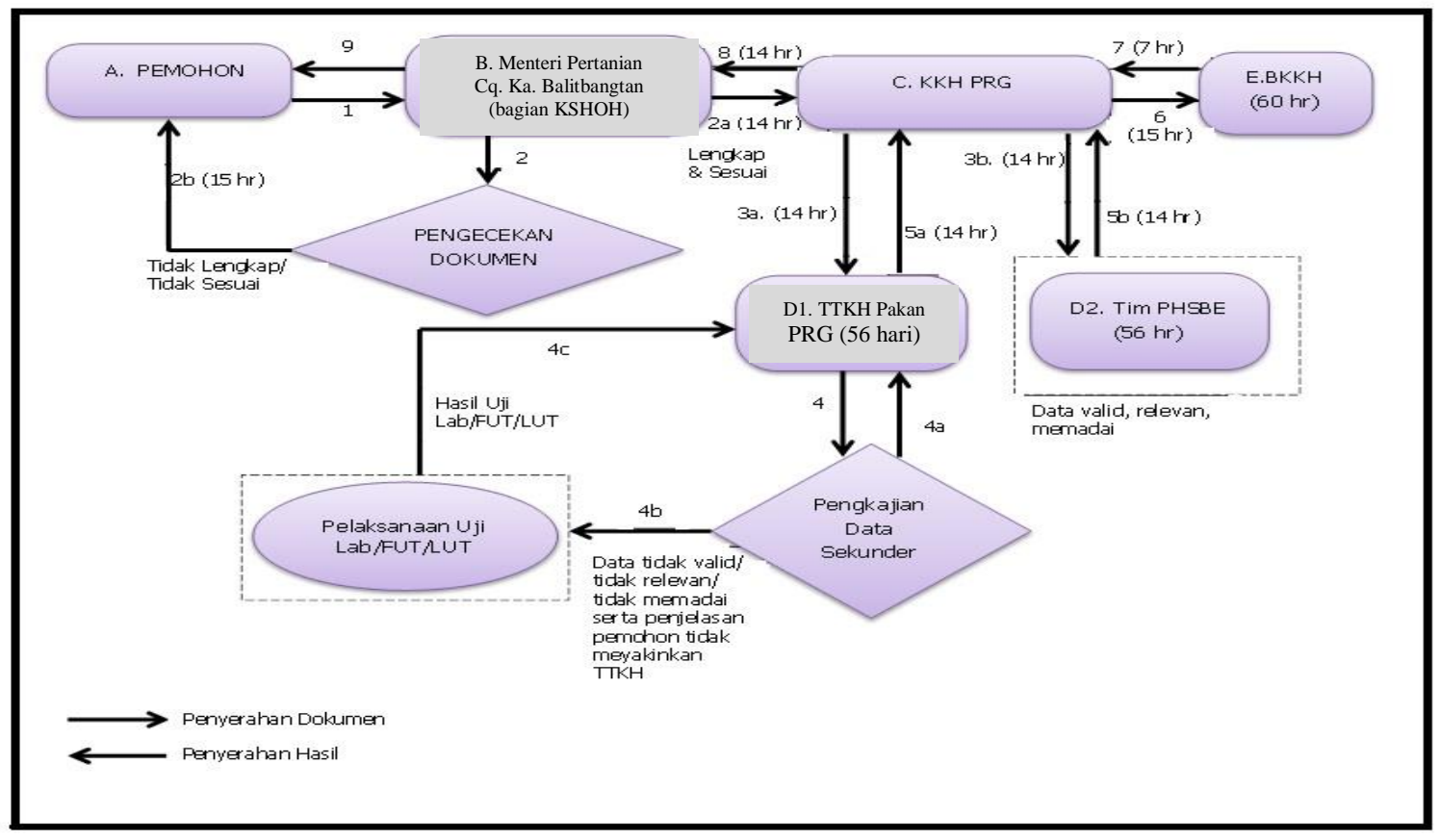

Gambar 1. Alur proses permohonan sertifikat aman pakan PRG

\section{KESIMPULAN}

Dengan telah diterbitkan Permentan Nomor 36/Permentan/LB.070/8/2016 dan SK Kepala Balitbangtan Nomor 466.2/Kpts/OT.210/H/11/2016, maka prosedur pengkajian keamanan pakan PRG di Indonesia mengikuti peraturan tersebut. Mengingat bahwa banyak produk rekayasa genetik sudah masuk ke Indonesia sejak tahun 1990, serta beberapa lembaga nasional yang juga melakukan perakitan PRG, maka pemerintah perlu menerbitkan peraturan tentang pengawasan dan pengendalian tanaman PRG yang beredar dan dimanfaatkan di Indonesia untuk melindungi masyarakat. Tim Teknis Keamanan 
Hayati Pakan PRG diharapkan dapat merespon dinamika yang berkembang di tataran global dan nasional melalui hasil kajian yang akurat.

\section{DAFTAR PUSTAKA}

Balitbangtan. 2016. Keputusan Kepala Badan Penelitian dan Pengembangan Pertanian Nomor: 446.2/ Kpts/OT.210/H/11/2016 tentang Pedoman Teknis Tata Cara dan Mekanisme Pengkajian Keamanan Pakan Produk Rekayasa Genetik. Jakarta (Indonesia): Badan Penelitian dan Pengembangan Pertanian.

Gideon A. 2017. Produksi terus naik, swasembada jagung bisa terwujud akhir tahun 2017 [Internet]. [cited 2 Februari 2017]. Available from: http://www.bisnis.liputan6.com/read/ 3021613. 13 Juli 2007.

Idris M. 2017. RI targetkan tak lagi impor jagung di tahun 2017 [Internet]. [cited 2 Februari 2017]. Available from: https://finance.detik.com/berita-ekonomi-bisnis/3411628

James C. 2015. Global status of commercialized biotech/GM crops:2015. ISAAA Brief 51. New York (US): The International Service for the Acquisition of Agri-biotech Applications (ISAAA).

Kemenperin. 2016. Agribisnis online. Kementerian Perindustrian [Internet]. [cited 10 Januari 2017]. Available from: Agribisnis.co.id/melihat-kebutuhan-jagung-nasional-di-tahun-2016/

Kementan. 2015. Peraturan Menteri Pertanian Republik Indonesia Nomor 19/Permentan/HK.140/4/2015 tentang Rencana Strategis Kementerian Pertanian Tahun 20152019. Jakarta (Indonesia): Kementerian Pertanian.

Kementan. 2016. Peraturan Menteri Pertanian Republik Indonesia Nomor 36/Permentan/LB.070/8/2016 tentang Pengkajian Keamanan Pakan Produk Rekayasa Genetik. Jakarta (Indonesia): Badan Penelitian dan Pengembangan Pertanian.

Peraturan Pemerintah Republik Indonesia Nomor 21 Tahun 2005 tentang Keamanan Hayati Produk Rekayasa Genetik.

Sudirman. 2015. Konsumsi pakan ternak. Kontan [Internet]. [cited 14 Desember 2016.]. Available from: https://industri kontan.co.id/news/konsumsi-pakan-ternak

Tiesnamurti B, Amirhusein B, Muharsini S, Purwantari ND, Sartika T, Widiawati Y, Trijatmiko R, Sutoro, Widyastuti Y, Sudarsono, Soejoedono RD, Imron, Ath-Thar MHF. 2016. Naskah akademik pedoman pengkajian keamanan pakan produk rekayasa genetik. Jakarta (Indonesia): IAARD Press.

Undang-Undang Republik Indonesia Nomor 21 Tahun 2004 tentang Pengesahan Cartagena Protocol on Biosafety to the Convention on Biological Diversity (Protokol Cartagena tentang Keamanan Hayati atas Konvensi tentang Keanekaragaman Hayati).

\section{DISKUSI}

\section{Pertanyaan}

1. Ketika produk tidak dijual bebas di negara asal, Permentan tersebut sebagai bentuk kehati-hatian kita terhadap produk rekayasa genetik (PRG). Sejauh mana atau produk apa saja yang sudah punya sertifikat PRG?

2. Apakah sudah ada sistem monitoring secara periodik untuk mengetahui produk yang telah beredar masih aman setelah periode waktu tertentu? 
3. Kalau ada sistem monitoring, laboratorium atau instansi mana yang menentukan produk tersebut masih layak untuk diedarkan?

4. Kalau untuk shorgum bagaimana apakah sudah ada PRG-nya? Kalau ada apakah sudah ada sertifikat keamanannya?

\section{Jawaban}

1. Produk yang sudah mempunyai sertifikat PRG yaitu: (1) Jagung tahan penggerek Mon 89034; dan (2) Jagung toleran herbisida NK 603.

2. Untuk sistem monitoring, Permentan masih dalam proses yaitu Permentan tentang "Pengawasan dan pengendalian varietas tanaman PRG pertanian yang beredar dan dimanfaatkan di wilayah RI”. Untuk koordinasi dengan biro hukum sepertinya masih perlu iterasi lagi dengan beberapa eselon I di lingkup pertanian agar tidak bertentangan dengan peraturan yang sudah ada. Untuk pertanyaan monitoring berapa lama, belum dapat dipastikan masih akan didiskusikan. Untuk monitoring dimulai pada tahun ketiga.

3. Institusi yang bertanggungjawab adalah BB Biogen.

4. Di Indonesia shorgum belum ada PRG-nya, yang sudah ada masih jagung dan kedelai. Kalau ada PRG shorgum malah dapat menjadi info buat kami dan sampai saat ini kita juga belum impor shorgum. 


\section{Lampiran 1. Daftar pertanyaan untuk pemohon}

\section{Informasi pakan PRG}

1. Apakah nama spesies/varietas/ras pakan PRG yang akan diusulkan untuk dikaji?

2. Berikan keterangan tentang sifat fisik dan stabilitas nilai gizi pakan PRG dibandingkan dengan pakan non-PRG.

3. Apakah pakan PRG ini berasal dari impor? Kalau ya, berikan dokumen perizinan atau penilaiannya dari instansi yang berwenang di negara asal.

4. Apakah pemanfaatan pakan PRG yang sama atau serupa pernah dilakukan sebelumnya di luar negeri? Berikan penjelasan.

5. Apakah tujuan pemohon dalam pengajuan permohonan ini (untuk memproduksi atau mengimpor pakan PRG)?

6. Apa keunggulan pakan PRG dibandingkan dengan pakan konvensional?

7. Apakah pakan PRG tersebut ditujukan untuk jenis ternak tertentu?

8. Apakah pemanfaatan pakan PRG yang sama pernah dilakukan sebelumnya di Indonesia? Kalau pernah, apa akibat yang menguntungkan atau merugikan di masyarakat?

9. Apakah organisme donor DNA telah biasa dipakai dalam produksi sebagai pakan? Jelaskan.

10. Sebutkan kesepadanan substansial antara pakan PRG dengan pakan non-PRG dalam spesies yang sama.

\section{Informasi genetik}

1. Sebutkan informasi sumber genetik dan DNA yang disisipkan:

a) Deskripsi karakterisitik komponen DNA sisipan, sumber dan fungsinya.

b) Apakah sumber pakan PRG mengandung gen yang bersifat alergenik dan toksik? Bila tidak, buktikan bahwa DNA sisipan tidak mengandung gen yang dapat menimbulkan toksisitas dan alergenisitas.

c) Jelaskan konstruksi vektor, metode transformasi dan seleksi.

d) Apakah DNA sisipan mengandung gen penyandi resistensi terhadap antibiotik?

e) Apabila terdapat gen yang telah dihilangkan atau diaktifkan, sebutkan tahapan prosedur yang digunakan.

2. Bagaimana sifat fenotipe dan genotipe organisme yang telah dimodifikasi dibandingkan dengan organisme asal?

3. Apakah terdapat kemungkinan gen yang disisipkan pada pakan PRG dipindahkan ke organisme lain? Apabila ya,

a) Berikan keterangan ke organisme apa dan berikan daftar yang sudah diuji?

b) Bagaimanakah mekanisme pemindahannya?

c) Pengaruh buruk apakah yang timbul akibat pemindahan sifat itu?

\section{Keamanan pakan PRG}

1. Apakah nilai gizi pakan PRG berubah melalui modifikasi genetik? Apakah terjadi perubahan kadar zat gizi utama? Kalau ya, bagaimana perubahannya?

2. Apakah terjadi perubahan dan atau pembentukan zat antinutrisi? Bila ya jelaskan.

3. Apakah pakan PRG mengandung protein baru? Bila ya, apakah protein baru tersebut sama dengan protein yang lazim dikonsumsi?

4. Apakah telah dilakukan penilaian keamanan untuk protein yang dihasilkan? Jelaskan. 
5. Apakah pernah dilakukan uji toksisitas terhadap pakan PRG termasuk metabolitnya? Kalau ya, berikan data dan informasi mengenai pengaruhnya pada ternak dan aspek toksisitasnya.

6. Apakah setiap produk metabolit dan pakan PRG tersebut bersifat akumulatif dalam rantai pakan sehingga pada kadar yang tinggi berpotensi menjadi racun? Kalau ya, uraikan lebih rinci dan cara penanggulangannya.

7. Apabila bahan pakan PRG merupakan gabungan lebih dari satu pakan PRG, apakah dapat menimbulkan interaksi yang meningkatkan risiko keamanan pakan? Apabila ya, bagaimana akibat yang mungkin terjadi?

\section{Feeding trial}

Apakah telah dilakukan feeding trial terhadap bahan pakan PRG? Jelaskan waktu, tempat, metode pelaksanaan serta ternak yang dipergunakan.

\section{Proses produksi dan peredaran}

1. Bagaimana rencana yang akan dilakukan setelah proses produksi dan peredaran?

2. Bagaimana rencana pemantauan dan evaluasi keamanan pakan setelah peredaran (post market surveillance)?

3. Tindakan apa yang akan diambil apabila terjadi bahaya yang mungkin timbul dalam produksi dan pemanfaatan pakan PRG?

4. Bagaimana cara penanganan limbah dalam produksi pakan olahan yang berasal dari pakan PRG? 